\title{
Characterization of ZnO Substituted 45S5 Bioactive Glasses and Glass - Ceramics
}

\author{
Ankesh Kumar Srivastava (Corresponding author) \\ Department of Ceramic Engineering \\ Institute of Technology, Banaras Hindu University \\ Varanasi 221005, India \\ E-mail: ankesh.000@gmail.com \\ Ram Pyare \\ Department of Ceramic Engineering \\ Institute of Technology, Banaras Hindu University \\ Varanasi 221005, India
}

Received: January 29, 2012

Accepted: February 8, 2012 Published: Apri1 1, 2012

URL: http://dx.doi.org/10.5539/jmsr.v1n2p207

doi:10.5539/jmsr.v1n2p207

\begin{abstract}
$\mathrm{ZnO}$ substituted 45S5 bioactive - glasses and glass - ceramics were prepared. In vitro bioactivity of bioactive glasses and glass - ceramics, before and after exposed to simulated body fluid (SBF) solution for different time periods, were investigated by fourier transform infrared (FTIR) reflectance spectrometer with measuring the $\mathrm{pH}$ and the concentrations of silicon, sodium, calcium, phosphorus and zinc ions in SBF solution. The density, micro hardness and flexural strength of bioactive glasses and glass - ceramics were measured. Experimental results show that in vitro bioactivity nearly remains same by doping $1 \%$ of $\mathrm{ZnO}$ by weight, but after that as well as $\mathrm{ZnO}$ content increases in vitro bioactivity decreases. Crystallization of bioactive glasses decreases in vitro bioactivity. The density, micro hardness and flexural strength of bioactive glass - ceramics are higher than their respective bioactive glasses and these are also increasing with the increase of $\mathrm{ZnO}$ content.
\end{abstract}

Keywords: Biomaterials, Bioactive glasses, Bioactive glass - ceramics, Physical properties, Bioactivity, Mechanical properties

\section{Introduction}

Any material that undergoes specific surface reactions, when implanted into the body, leading to the formation of a hydroxyl - carbonate apatite (HCA) layer that is responsible for the formation of a firm bond with tissues is called bioactive material (Kokubo, 1991). Some bioactive materials, which are used clinically, are: bioactive glasses in the $\mathrm{SiO}_{2}-\mathrm{Na}_{2} \mathrm{O}-\mathrm{CaO}-\mathrm{P}_{2} \mathrm{O}_{5}$ system (Ogino et al., 1980), bioactive glass - ceramic A - W containing crystalline oxyfluoroapatite $\left[\mathrm{Ca}_{10}\left(\mathrm{PO}_{4}\right)_{6}(\mathrm{O}, \mathrm{F})_{2}\right]$ and $\beta$ - wollastonite $\left[\mathrm{CaO} . \mathrm{SiO}_{2}\right]$ in a $\mathrm{MgO}-\mathrm{CaO}-\mathrm{SiO}_{2}$ glassy matrix (Kokubo et al., 1990), hydroxyapatite (HA) $\left[\mathrm{Ca}_{10}\left(\mathrm{PO}_{4}\right)_{6}(\mathrm{OH})_{2}\right]$ (Jarcho, et al., 1977) and $\beta$ - tricalcium phosphate (TCP) $\left[\mathrm{Ca}_{3}\left(\mathrm{PO}_{4}\right)_{2}\right]$ (Rejda, et al., 1977).

The most widely researched bioactive material is $45 \mathrm{~S} 5$ bioactive glass [Composition wt. \% $45 \mathrm{SiO}_{2}-24.5 \mathrm{Na}_{2} \mathrm{O}$ - $24.5 \mathrm{CaO}-6 \mathrm{P}_{2} \mathrm{O}_{5}$ ], where $\mathrm{S}$ denotes the network former $\mathrm{SiO}_{2}$ in $45 \%$ by weight followed by a specific $\mathrm{Ca} / \mathrm{P}$ molar ratio 5 (Best, et al., 2008). It was invented by Hench in 1969. 45S5 bioactive glass is clinically used for middle ear prostheses and as endosseous ridge implants (Lin, et al., 2005). Although 45S5 bioactive glass remains the gold standard for bioactive glasses, but it has several limitations. A major disadvantage of $45 \mathrm{~S} 5$ bioactive glass is connected to its slow degradation rate. In addition, the mechanical properties of 45S5 bioactive glass are not completely adequate for significant load - bearing applications (Aina, et al., 2009). By adjusting the oxide composition of $45 \mathrm{~S} 5$ bioactive glass, its properties and rate of bonding to tissues can be controlled. Previous studies (Lusvardi, et al., 2009) have shown that the substitution of $5-15 \% \mathrm{~B}_{2} \mathrm{O}_{3}$ for $\mathrm{SiO}_{2}$ or $12.5 \%$ $\mathrm{CaF}_{2}$ for $\mathrm{CaO}$ or $\mathrm{Na}_{2} \mathrm{O}$ in $45 \mathrm{~S} 5$ bioactive glass has minor effect on the ability of this bioactive glass to form a 
tissue bond. Some authors (Clupper, et al., 2001) argued that the crystallization of 45S5 bioactive glass has a little effect on the ability of this bioactive glass to form a tissue bond.

A first aim of the present investigation is to determine the bioactive behaviour of $\mathrm{ZnO}$ substituted $45 \mathrm{~S} 5$ bioactive glasses and glass - ceramics since zinc is a trace element that shows stimulatory effects on bone formation (Rahaman, et al., 2011). A further aim of this investigation is to determine the density, micro hardness and flexural strength of these bioactive glasses and glass - ceramics.

\section{Experimental}

\subsection{Preparation of Bioactive Glasses and Glass - ceramics}

The bioactive glasses, the compositions of which are given in Table 1, were prepared by employing normal melting and annealing techniques. For preparation of bioactive glasses: fine grained quartz (Merck, India) was used as the source of $\mathrm{SiO}_{2}$, anhydrous sodium carbonate $\left[\mathrm{Na}_{2} \mathrm{CO}_{3}\right]$ (Merck, India) was used as the source of $\mathrm{Na}_{2} \mathrm{O}$, anhydrous calcium carbonate $\left[\mathrm{CaCO}_{3}\right]$ (Merck, India) was used as the source of $\mathrm{CaO}$, ammonium dehydrogenate orthophosphate $\left[\mathrm{NH}_{4} \mathrm{H}_{2} \mathrm{PO}_{4}\right]$ (Merck, India) was used as the source of $\mathrm{P}_{2} \mathrm{O}_{5}$ while $\mathrm{ZnO}$ (Merck, India) was added as such. All the materials were of analytical grade chemicals and used without further purification. The weighed batches were homogeneously mixed using an agate mortar and pestle before melting in alumina crucibles for 3 hours in an electric furnace at the temperature $1400 \pm 10{ }^{\circ} \mathrm{C}$. The homogeneous melts were cast into preheated stainless steel moulds of the required dimensions. The prepared bioactive glass samples were directly transferred to a regulated muffle furnace at the temperature $500{ }^{\circ} \mathrm{C}$ for annealing. After $1 \mathrm{~h}$, the muffle furnace was left to cool to room temperature at a rate of $30^{\circ} \mathrm{C} / \mathrm{h}$.

In order to obtain the bioactive glass - ceramics, the bioactive glass samples were heated in the muffle furnace in two step regime at the deduced temperatures and times as shown in Table 2. These temperatures were obtained from differential thermal analysis (DTA) of bioactive glasses. Each bioactive glass sample was first heated slowly to the nucleation temperature for the formation of sufficient nuclei sites and after holding for the definite time, was then further heated to reach the crystallization temperature for performing the perfect crystal growth process and after a second hold for the specific time, the sample was left to cool inside the muffle furnace to room temperature at a rate of $20^{\circ} \mathrm{C} / \mathrm{h}$.

\subsection{Physical Analysis}

In order to determine glass nucleation and crystallization temperature, differential thermal analysis (DTA) was carried out on bioactive glass samples. Fine powder of bioactive glasses was made using an agate mortar and pestle and analyzed using a differential thermal analyzer (Perkin Elmer Diamond, USA) at a heating rate of 10 ${ }^{0} \mathrm{C} / \mathrm{min}$ under a stream of argon atmosphere using alumina as a reference material. DTA was carried out from the temperature $300^{\circ} \mathrm{C}$ to $900{ }^{\circ} \mathrm{C}$. Identification of the crystalline phases after heat - treatment of bioactive glass samples was carried out by $\mathrm{X}$ - ray diffraction (XRD) analysis. Fine powder of bioactive glass - ceramics was made using an agate mortar and pestle and examined using a X - ray diffractometer (Bruker AXS, Model: D8 Advance, UK), adopting Ni filter and $\mathrm{Cu}$ target with voltage of $40 \mathrm{KV}$ and a current of $25 \mathrm{~mA}$. The XRD patterns were recorded in a $2 \theta$ range of $10-70^{\circ}$. The JCPDS - International Center for Diffraction Data Cards was used as a reference data for the interpretation of XRD patterns in the present work.

\subsection{In Vitro Bioactivity Tests}

In 1991 Kokubo developed simulated body fluid (SBF), which has become the most widely used solution for in vitro investigation of bioactivity of bioactive materials by providing conditions very close to those found in vivo. The ion concentration of simulated body fluid is nearly equal to that of human blood plasma and is given in Table 3 (Kokubo, et al., 2006). The simulated body fluid (SBF) solution was prepared by dissolving the required amounts of reagent grade chemicals (Merck, India), the sodium chloride $[\mathrm{NaCl}]$, sodium bicarbonate $\left[\mathrm{NaHCO}_{3}\right]$, potassium chloride $[\mathrm{KCl}]$, di - potassium hydrogen phosphate trihydrate $\left[\mathrm{K}_{2} \mathrm{HPO}_{4} \cdot 3 \mathrm{H}_{2} \mathrm{O}\right]$, magnesium chloride hexahydrate $\left[\mathrm{MgCl}_{2} \cdot 6 \mathrm{H}_{2} \mathrm{O}\right]$, calcium chloride dehydrate $\left[\mathrm{CaCl}_{2} \cdot 2 \mathrm{H}_{2} \mathrm{O}\right]$ and sodium sulphate $\left[\mathrm{Na}_{2} \mathrm{SO}_{4}\right]$ in distilled water. It was buffered at a $\mathrm{pH}$ value of 7.40 with $50 \mathrm{mM}$ tris (hydroxymethyl) aminomethane $\left[\mathrm{NH}_{2} \mathrm{C}\left(\mathrm{CH}_{2} \mathrm{OH}\right)_{3}\right]$ and $1 \mathrm{~N}$ - hydrochloric $[\mathrm{HCl}]$ acid at the temperature $37^{\circ} \mathrm{C}$.

We carried out in vitro studies by soaking polished pieces with dimension $10 \mathrm{~mm}$ x $10 \mathrm{~mm}$ x $2 \mathrm{~mm}$ of each bioactive glass and glass - ceramic sample in $50 \mathrm{ml} \mathrm{SBF}$ solution, at the temperature $37{ }^{\circ} \mathrm{C}$, for $1,3,7$ and 15 days. After soaking, the samples were filtered, rinsed with distilled water, and dried in an air oven at the temperature $150{ }^{\circ} \mathrm{C}$ for 24 hours. Identification of the structural groups of bioactive glass and glass - ceramic samples before and after soaking in SBF solution was carried out by fourier transform infrared (FTIR) reflectance spectrometric investigation. Fine powder of bioactive glasses and glass - ceramics was made using an agate mortar and pestle and investigated by fourier transform infrared reflectance spectrometer (Impact 420, 
Nicolet Instruments, USA) at $2 \mathrm{~cm}^{-1}$ resolution with reference to KBr. FTIR spectra were recorded between wavenumber 1400 and $400 \mathrm{~cm}^{-1}$. The elemental concentration of the SBF solution, before and after soaking of bioactive glass and glass - ceramic samples, were examined by atomic absorption spectroscopy (AAS, Model Spectra AA, 220FS). The $\mathrm{pH}$ of the SBF solution, before and after soaking of bioactive glass and glass - ceramic samples, was recorded by $\mathrm{pH}$ meter (Thermo Orion, Model: 720A, USA).

\subsection{Density and Mechanical Properties Measurements}

Archimedes principle was employed to obtain the density of bioactive glass and glass - ceramic samples using distilled water as buoyant. All the weight measurements have been made using a digital balance (Sartorius, Model: BP221S, USA) having an accuracy of $\pm 0.0001 \mathrm{~g}$. Density $(\rho)$ of sample was obtained employing the relation (1) (Rajendran, et al., 2002) as given below:

$$
\rho=\frac{w_{a}}{w_{a}-w_{b}} \rho_{b}
$$

where $w_{a}$ is the weight of sample in air, $w_{b}$ is the weight of sample in buoyant and $\rho_{b}$ is the density of buoyant.

Micro indentations were made on the polished surfaces of bioactive glass and glass - ceramic specimens using a diamond Vickers indenter on a micro hardness testing machine (Future - Tech Corp, Tokyo, Model FM - 7e, Japan). The size of the specimen was $10 \mathrm{~mm} \times 10 \mathrm{~mm} \times 10 \mathrm{~mm}$ according to ASTM Standard: C730 - 98. The indentations have been made for loads ranging between $30 \mathrm{mN}$ and $2000 \mathrm{mN}$, applied at a velocity of $1 \mathrm{~mm} / \mathrm{s}$ and allowed to equilibrate for 15 seconds before measurement. Micro hardness $(H)$ (GPa) of specimen is calculated using the formula (2) (Michel, et al., 2004) as given below:

$$
H=1.854 \frac{P}{d^{2}}
$$

where $P(\mathrm{~N})$ is the applied load on specimen and $d(\mathrm{~m})$ is the diagonal of the impression.

Three points flexural strength tests were carried out for polished bioactive glass and glass - ceramic specimens, using a universal testing machine (Instron Corp, Canton, MA, Model 5500R, USA). The size of the specimen was $4 \mathrm{~mm} \times 4 \mathrm{~mm} \times 50 \mathrm{~mm}$ according to ASTM Standard: C158 - 02. The load was applied over a $40 \mathrm{~mm}$ span and at the mid - point of the $4 \mathrm{~mm} \times 40 \mathrm{~mm}$ surface using a cross - head speed of $0.5 \mathrm{~mm} / \mathrm{min}$. Flexural Strength $\left(\sigma_{f}\right)$ of specimen is calculated using the formula (3) (Chen, et al., 2006) as given below:

$$
\sigma_{f}=\frac{3 P_{f} L}{2 b h^{2}}
$$

where $P_{f}$ is the load at which specimen being fractured, $L$ is the length of specimen over which the load is applied, $b$ is the width of specimen, and $h$ is the height of specimen.

\section{Results}

\subsection{Physical Analysis}

\subsubsection{Differential Thermal Analysis (DTA)}

The differential thermal analysis (DTA) plots of bioactive glasses are shown in Figure 1. The DTA plots indicate that the incorporation of $\mathrm{ZnO}$ content in the base bioactive glass (45S5) causes a decrease in its exothermic peak temperature. The endothermic peak temperature of the base bioactive glass (45S5) also decreases with the addition of $\mathrm{ZnO}$ content in it but decrease in endothermic peak temperature is minor.

\subsubsection{The X - Ray Diffraction (XRD) Analysis}

The $\mathrm{X}$ - ray diffraction (XRD) patterns for bioactive glass - ceramics are shown in Figure 2. The XRD patterns of all the bioactive glass - ceramics show the presence of crystalline phases of sodium calcium silicate $\left[\mathrm{Na}_{2} \mathrm{Ca}_{2}\right.$ $\mathrm{Si}_{3} \mathrm{O}_{9}$ (card number: PDF \# 01 - 1078 \& PDF \# 02 - 0961), $\mathrm{Na}_{2} \mathrm{CaSi}_{3} \mathrm{O}_{8}$ (card number: PDF \# 12 - 0671)].

\subsection{In Vitro Bioactivity Tests}

\subsubsection{Fourier Transform Infrared (FTIR) Reflectance Spectrometric Investigation}

The fourier transform infrared (FTIR) reflectance spectra of bioactive glass 45S5 and its glass - ceramic 45S5C, before and after soaking in simulated body fluid (SBF) solution for a period of $1,3,7$, and 15 days are given in Figure 3. The FTIR reflectance spectra of bioactive glass 45S5 before soaking in SBF solution (Figure 3A (a)) 
reveals sharp peaks at wavenumbers 471, 930 and $1100 \mathrm{~cm}^{-1}$ while its glass - ceramic 45S5C (Figure 3B (a)) shows additional peaks at wavenumbers 580,650 and $1041 \mathrm{~cm}^{-1}$.

Following changes were observed in the FTIR reflectance spectra of bioactive glass $45 \mathrm{~S} 5$ at various reaction times (Figure 3A). After soaking for 1 day in SBF solution peak at wavenumber $471 \mathrm{~cm}^{-1}$ shifted to lower wavenumber at $461 \mathrm{~cm}^{-1}$ and peak at wavenumber $1100 \mathrm{~cm}^{-1}$ shifted to higher wavenumber at $1125 \mathrm{~cm}^{-1}$ with decreasing their intensity, while the peak at wavenumber $930 \mathrm{~cm}^{-1}$ had disappeared. Appearance of new peaks at wavenumbers 557, 607, 794, 871, 1050, and $1250 \mathrm{~cm}^{-1}$ were observed. After 3 days the intensity of peaks at wavenumbers $557,794,1125,1250 \mathrm{~cm}^{-1}$ decreased while the intensity of the peaks at wavenumbers 607,871 , $1050 \mathrm{~cm}^{-1}$ increased. After 7 days peak at wavenumber $471 \mathrm{~cm}^{-1}$ had disappeared. The appearance of peak at wavenumber $527 \mathrm{~cm}^{-1}$ was observed. After 15 days, peaks at wavenumbers $527,607,871,1050 \mathrm{~cm}^{-1}$ were dominant in the FTIR reflectance spectra. Similar changes were observed in the FTIR reflectance spectra of bioactive glass - ceramic $45 \mathrm{~S} 5 \mathrm{C}$ at various reaction times (Figure 3B). Additional peaks at wavenumbers 580, 650 and $1041 \mathrm{~cm}^{-1}$ in bioactive glass - ceramic 45S5C had disappeared after soaking for 1 day in SBF solution.

Careful inspection of FTIR reflectance spectra of all the ZnO substituted bioactive glasses (Z1, Z2, Z3 and Z4) in comparison with the base bioactive glass (45S5) reveals minor or limited variation of the positions and intensities of the reflectance peaks. The main differences can be summarized in bioactive glasses, where there was a time delay in the formation of peaks at wavenumbers 527 and $607 \mathrm{~cm}^{-1}$. After soaking for 15 days in SBF solution (Figure 4A) it was found that the intensity of peak at these wavenumbers nearly remains same by doping of $1 \% \mathrm{ZnO}$ by weight with respect to parent bioactive glass (45S5), but afterwards as well as $\mathrm{ZnO}$ content increases a decrease in intensity was observed. The FTIR reflectance spectra of bioactive glasses and glass - ceramics after soaking for 15 days in SBF solution (Figure 4) shows that peaks at wavenumbers 527 and $607 \mathrm{~cm}^{-1}$ was found less intense in the bioactive glass - ceramics than their respective bioactive glasses.

\subsubsection{Ion Release Analysis}

Variations of $\mathrm{Si}, \mathrm{Na}, \mathrm{Ca}, \mathrm{P}$ and $\mathrm{Zn}$ concentration in simulated body fluid (SBF) solution that was taken before and after soaking of bioactive glasses and glasses - ceramics for a period of 1, 3, 7 and 15 days, are shown in Figure 5. As can be observed in all cases that Si concentration in SBF solution increased during first 7 days of soaking and then a slight decrease was obtained. Na concentration increased rapidly during first 3 days of soaking and then it attains nearly a constant value where as $\mathrm{Ca}$ concentration increased during first day of soaking and then it decreased continuously. Increase in $\mathrm{Zn}$ concentration and a decrease in P concentration were also observed. It was also observed that the addition of $\mathrm{ZnO}$ in the base bioactive glass (45S5) decreases the leaching rate of ions and crystallization of bioactive glasses also decreases the leaching rate of ions.

\section{$3.2 .3 \mathrm{pH}$ Measurements}

The variation in $\mathrm{pH}$ values of simulated body fluid $(\mathrm{SBF})$ solution that was taken before and after soaking of bioactive glasses and glasses - ceramics for a period of 1, 3, 7 and 15 days, is shown in Figure 6 . The $\mathrm{pH}$ value of SBF solution increased during first 3 days of soaking and then it attained nearly a constant value in all cases. It was also observed that the addition of $\mathrm{ZnO}$ in the base bioactive glass (45S5) causes an initial decrease in the $\mathrm{pH}$ value. Crystallization of bioactive glasses also decreases the initial $\mathrm{pH}$ value of SBF solution.

\subsection{Density and Mechanical Properties Measurements}

Experimental values of density, micro hardness and flexural strength of bioactive glasses and glass - ceramics are given in Table 4. It has been observed that the increase of $\mathrm{ZnO}$ in the base bioactive glass (45S5) causes an increase in its density, micro hardness and flexural strength. It also has been observed that the density, micro hardness and flexural strength of bioactive glass - ceramics are higher than their respective bioactive glasses.

\section{Discussions}

\subsection{Physical Analysis}

\subsubsection{Differential Thermal Analysis (DTA)}

In the differential thermal analysis (DTA) plots of bioactive glasses (Figure 1) endothermic peaks show the nucleation region and the exothermic peaks correspond to the crystallization process. It has been reported that addition of $\mathrm{ZnO}$ decreases the viscosity of silicate glasses (Doremus, 1994). Increasing the content of $\mathrm{ZnO}$ in the base bioactive glass (45S5) resulted in the movement of endothermic as well as exothermic peaks to lower temperatures. This can be attributed to the decrease of viscosity with the increase of $\mathrm{ZnO}$ content in the base bioactive glass (45S5) (Alizadeh, et al., 2000). 


\subsubsection{X - Ray Diffraction (XRD) Analysis}

The XRD patterns of all the bioactive glass - ceramics show the presence of crystalline phases. The reason for the ease of crystallization of bioactive glasses can be correlated with the presence of silicate and phosphate network, as well as the possible phase separation even in micro scale of the two phases on heat - treatment. It is well known that the addition of a few percentages of $\mathrm{P}_{2} \mathrm{O}_{5}$ to silicate glass compositions, promotes the volume nucleation and glass - ceramic formation (ElBatal, et al., 2008). There is some evidence for precipitation of phosphate crystals which subsequently act as heterogeneous nucleation sites for the subsequent crystallization of the major phases, although the detailed role of $\mathrm{P}_{2} \mathrm{O}_{5}$ remains to be discussed (James, 1995). Previous studies (Hench, et al., 1971, Hench, et al., 1973, Mastelaro, et al., 2000) have shown that the heat - treatment of 45S5 bioactive glass at a nucleation temperature of $550{ }^{\circ} \mathrm{C}$ and followed by heating at a crystallization temperature of $680{ }^{\circ} \mathrm{C}$ produces a bioactive glass - ceramic containing the sodium calcium silicate $\left[\mathrm{Na}_{2} \mathrm{Ca}_{2} \mathrm{Si}_{3} \mathrm{O}_{9}\right]$ as a main crystalline phase. In all the bioactive glass - ceramics sodium calcium silicate $\left[\mathrm{Na}_{2} \mathrm{Ca}_{2} \mathrm{Si}_{3} \mathrm{O}_{9}\right.$ \& $\left.\mathrm{Na}_{2} \mathrm{CaSi}_{3} \mathrm{O}_{8}\right]$ is present as a main crystalline phase (Figure 2). The studied bioactive glass - ceramics did not contain $\mathrm{Zn}$ as separate crystalline phases. This can be related to their relatively low content in the bioactive glasses composition.

\subsection{In Vitro Bioactivity Tests}

\subsubsection{Fourier Transform Infrared (FTIR) Reflectance Spectrometric Investigation}

The fourier transform infrared (FTIR) reflectance spectra of bioactive glasses and glass - ceramics before immersion in simulated body fluid (SBF) solution reveal $\mathrm{Si}-\mathrm{O}$ - Si bending $\left(500-400 \mathrm{~cm}^{-1}\right), \mathrm{Si}-\mathrm{O}$ stretching $\left(940-860 \mathrm{~cm}^{-1}\right)$ and $\mathrm{Si}-\mathrm{O}-\mathrm{Si}$ stretching (asymmetric) $\left(1200-970 \mathrm{~cm}^{-1}\right)$ bands, which are known and accepted to be mainly characteristic of silicate network (Serra, et al., 2002, Marchi, et al., 2005, Wang, et al., 2011). This may be attributed to the presence of major $\mathrm{SiO}_{2}$ as a basic building constituent. The FTIR reflectance spectra of bioactive glasses and glass - ceramics did not show separate bands to the presence of phosphate network and this may be due to the limited percentage of $\mathrm{P}_{2} \mathrm{O}_{5}$. The FTIR reflectance spectra of bioactive glass - ceramics also, show the additional bands at wavenumbers $650-619 \mathrm{~cm}^{-1}$ and $580-570 \mathrm{~cm}^{-1}$ which are due to the presence of sodium calcium silicate crystalline phase (ElBatal, et al., 2003). The FTIR reflectance spectra of bioactive glasses and glass - ceramics after soaking in simulated body fluid (SBF) solution for different times reveal $\mathrm{Si}$ - O - Si stretching (symmetric) $\left(820-770 \mathrm{~cm}^{-1}\right)$ and (asymmetric) $\left(1200-970 \mathrm{~cm}^{-1}\right)$ bands, which indicates the formation of silica - rich layer. The presence of $\mathrm{P}-\mathrm{O}$ bending (amorphous) $\left(560-550 \mathrm{~cm}^{-1}\right)$ bands indicates the formation of $\mathrm{CaO}-\mathrm{P}_{2} \mathrm{O}_{5}$ layer. Emerging of $\mathrm{P}-\mathrm{O}$ bending (crystalline) $\left(610-600 \mathrm{~cm}^{-1}\right.$ and $\left.530-515 \mathrm{~cm}^{-1}\right)$ bands indicates the formation of hydroxyl carbonate apatite (HCA) layer. Presence of C - O stretching (890 - 800 $\left.\mathrm{cm}^{-1}\right)$ bands shows the crystalline nature of HCA layer and $\mathrm{P}-\mathrm{O}$ stretching $\left(1040-910 \mathrm{~cm}^{-1}\right)$ bands are attributed due to presence of HCA layer (Filgueiras, et al., 1993, Filho, et al., 1996, Peitl, et al., 2001). Intensity of silica - rich layer and $\mathrm{CaO}-\mathrm{P}_{2} \mathrm{O}_{5}$ layer goes on decreasing but the intensity of HCA layer increases with time in all cases after soaking for 1 day in SBF solution. Hench et al. were the first to detail a number of sequential steps for in vitro and in vivo reactivity of silicate glasses that are responsible for the tissue bonding ability of these glasses. Briefly, these involve cation release from the glass with consequential increase in $\mathrm{pH}$ of solution, formation of silica - rich layer and precipitation of a $\mathrm{CaO}-\mathrm{P}_{2} \mathrm{O}_{5}$ rich layer that further crystallizes as HCA layer (Hench, 1991, Branda, et al., 1996, Balamurugan, et al., 2007). The degree of bioactivity in bioactive material is usually expressed by the formation of HCA surface. Finally, the FTIR reflectance spectra of bioactive glasses after soaking for 15 days in a SBF solution (Figure $4 \mathrm{~A}$ ) indicates that the addition of $1 \%$ of $\mathrm{ZnO}$ by weight in the base bioactive glass (45S5) shows no effect on the formation of HCA layer but after that as well as $\mathrm{ZnO}$ content increases a decrease in the formation of HCA layer was observed. This can be due to release of Si from the base bioactive glass (45S5) decreases with increasing of $\mathrm{ZnO}$ content in it since $\mathrm{ZnO}$ enhances the chemical stability of silicate glasses (ElBatal, et al., 2010). Therefore, the suppression of the formation of silica - rich layer leads to the suppression of $\mathrm{CaO}-\mathrm{P}_{2} \mathrm{O}_{5}$ layer and hence suppression of the formation of HCA surface. The FTIR reflectance spectra of bioactive glasses and glass - ceramics after soaking for 15 days in a SBF solution (Figure 4) shows that the formation of HCA layer on bioactive glass - ceramics are significantly less than their respective bioactive glasses. This phenomenon is explained by considering that the amorphous phase is usually more prone to ion leaching phenomena than crystalline phases (Verne, et al., 2009).

\subsubsection{Ion Release Analysis}

The quantitative determination of $\mathrm{Si}, \mathrm{Na}, \mathrm{Ca}, \mathrm{P}$ and $\mathrm{Zn}$ ions in simulated body fluid (SBF) solution for various times (Figure 5) is important to understand the kinetics of surface reactions in bioactive glasses and glass ceramics. During initial period of soaking faster release of $\mathrm{Ca}$ ions increases the concentration of $\mathrm{Ca}$ ions. Decrease in $\mathrm{Ca}$ concentration is due to formation of $\mathrm{CaO}-\mathrm{P}_{2} \mathrm{O}_{5}$ layer. The decrease in $\mathrm{P}$ concentration with a 
simultaneous increase in $\mathrm{Si}$ concentration is consistent with the formation of $\mathrm{CaO}-\mathrm{P}_{2} \mathrm{O}_{5}$ layer. The participation of $\mathrm{Zn}$ in the nucleation process can be ascertained by the observed variation in its concentration with soaking time.

\subsection{3 $\mathrm{pH}$ Measurements}

During initial period of soaking, faster release of $\mathrm{Ca}$ and $\mathrm{Na}$ ions increased the $\mathrm{pH}$ value, but after that $\mathrm{pH}$ attained nearly a constant value since the rate of release of $\mathrm{Na}$ ion decreased (Figure 6).

\subsection{Density and Mechanical Properties Measurements}

The increase of $\mathrm{ZnO}$ content in the base bioactive glass (45S5) leads to an increase its density because of replacement of a lighter element, $\mathrm{Si}\left(\right.$ density $=2.33 \mathrm{~g} / \mathrm{cm}^{3}$ ) with a heavier element, $\mathrm{Zn}\left(\right.$ density $\left.=7.14 \mathrm{~g} / \mathrm{cm}^{3}\right)$. The increase of $\mathrm{ZnO}$ content in the base bioactive glass (45S5), also leads to an increase its micro hardness and flexural strength. This is easily understood that the more the density of glass, the more the compactness of glass structure, and consequently, the more micro hardness and flexural strength. The density, micro hardness and flexural strength of bioactive glass - ceramics are higher than their respective bioactive glasses due to densification.

\section{Conclusions}

In the present investigation, a comparative study was made on physical, bioactive and mechanical properties of $\mathrm{ZnO}$ substituted $45 \mathrm{~S} 5$ bioactive glasses and glass - ceramics. The following conclusions are obtained from this investigation:

(1). Increasing the $\mathrm{ZnO}$ content in $45 \mathrm{~S} 5$ bioactive glass decreases its glass crystallization temperature. Increase of $\mathrm{ZnO}$ content in 45S5 bioactive glass also decreases its glass nucleation temperature but decrease in glass nucleation temperature is small. There is no effect on the formation of hydroxyl - carbonate apatite (HCA) layer by addition of $1 \%$ of $\mathrm{ZnO}$ by weight in $45 \mathrm{~S} 5$ bioactive glass, but increasing of $\mathrm{ZnO}$ content more than $1 \%$ decreases the formation of HCA layer. Increasing the $\mathrm{ZnO}$ content in $45 \mathrm{~S} 5$ bioactive glass enhances its chemical durability, density, micro hardness and flexural strength.

(2). Controlled crystallization of bioactive glasses produced crystalline phases of sodium calcium silicate $\left[\mathrm{Na}_{2} \mathrm{Ca}_{2} \mathrm{Si}_{3} \mathrm{O}_{9}\right.$ and $\left.\mathrm{Na}_{2} \mathrm{CaSi}_{3} \mathrm{O}_{8}\right]$. Crystallization of bioactive glasses shows a slight retardation in the formation of HCA layer, but enhances their chemical durability, density, micro hardness and flexural strength.

\section{References}

Aina, V., Malavasi, G., Fiorio Pla, A., Munaron, L., \& Morterra, C. (2009). Zinc - containing bioactive glasses: Surface reactivity and behaviour towards endothelial cells. Acta Biomaterialia, 5, 1211-1222. http://dx.doi.org/10.1016/j.actbio.2008.10.020

Alizadeh, P., \& Marghussian, V. K. (2000). The effect of compositional changes on the crystallization behaviour and mechanical properties of diopside - wollastonite glass - ceramics in the $\mathrm{SiO}_{2}-\mathrm{CaO}-\mathrm{MgO}\left(\mathrm{Na}_{2} \mathrm{O}\right)$ system. Journal of European Ceramic Society, 20, 765- 773. http://dx.doi.org/10.1016/S0955-2219(99)00135-1

Balamurugan, A., Balossier, G., Kannan, S., Michel, J., Rebelo, A. H. S., \& Ferreira, J. M. F. (2007). Development and in vitro characterization of sol - gel derived $\mathrm{CaO}-\mathrm{P}_{2} \mathrm{O}_{5}-\mathrm{SiO} 2-\mathrm{ZnO}$ bioglass. Acta Biomaterialia, 3, 255- 262. http://dx.doi.org/10.1016/j.actbio.2006.09.005

Best, S. M., Porter, A. E., Thian, E. S., \& Huang, J. (2008). Bioceramics: Past, present and for the future. Journal of European Ceramic Society, 28, 1319- 1327. http://dx.doi.org/10.1016/j.jeurceramsoc.2007.12.001

Branda, F., Fresa, R., Costantini, A., \& Buri, A. (1996). Bioactivity of $1.25 \mathrm{CaO}-\mathrm{SiO}_{2}$ glass: an FTIR and X Ray study on powered samples. Biomaterials, 17, 2247-2251. http://dx.doi.org/10.1016/0142-9612(95)00328-2

Chen, Q. Z., Thompson, I. D., \& Boccaccini, A. R. (2006). 45S5 Bioglasss - derived glass - ceramic scaffolds for bone tissue engineering. Biomaterials, 27, 2414- 2425. http://dx.doi.org/10.1016/j.biomaterials.2005.11.025

Clupper, D. C., Mecholsky Jr., J. J., LaTorre, G. P., \& Greenspan, D. C. (2001). Sintering temperature effects on the in vitro bioactive response of tape cast and sintered bioactive glass - ceramic in Tris buffer. Journal of Biomedical Materials $\quad$ Research, $\quad 57, \quad 532-540$. http://dx.doi.org/10.1002/1097-4636(20011215)57:4\%3C532::AID-JBM1199\%3E3.0.CO;2-3

Della Mea, G., Gasparotto, A., Bettinelli, M., Montenero, A., \& Scaglioni, R. (1986). Chemical durability of zinc containing glasses. Journal of Non - Crystalline Solids, 84, 443-451. http://dx.doi.org/10.1016/0022-3093(86)90808-2 
Doremus, R. H. (1994). Glass Science, 2nd edition. John Wiley \& Sons, Inc., New York, pp105.

ElBatal, H. A., Azooz, M. A., Khalil, E. M. A., Monem, A. S., \& Hamdy, Y. M. (2003). Characterization of some bioglass - ceramics. Materials Chemistry and Physics, 80, 599-609. http://dx.doi.org/10.1016/S0254-0584(03)00082-8

ElBatal, F. H., \& ElKheshen, A. (2008). Preparation and characterization of some substituted bioglasses and their ceramic derivatives from the system $\mathrm{SiO}_{2}-\mathrm{Na}_{2} \mathrm{O}-\mathrm{CaO}-\mathrm{P}_{2} \mathrm{O}_{5}$ and effect of gamma irradiation. Materials Chemistry and Physics, 110, 352-362. http://dx.doi.org/10.1016/j.matchemphys.2008.02.011

Filgueiras, M. R., LaTorre, G., \& Hench, L. L. (1993). Solution effects on the surface reactions of a bioactive glass. Journal of Biomedical Materials Research, 27, 445-453. http://dx.doi.org/10.1002\%2Fjbm.820270405

Filho, O. P., LaTorre, G. P., \& Hench, L. L. (1996). Effect of crystallization on apatite layer formation of bioactive glass 45S5. Journal of Biomedical Materials Research, 30, 509-514. http://dx.doi.org/10.1002/(SICI)1097-4636(199604)30:4\%3C509::AID-JBM9\%3E3.0.CO;2-T

James, P. F. (1995). Glass ceramics: new compositions and uses. Journal of Non - Crystalline Solids, 181, 1-15. http://dx.doi.org/10.1016/0022-3093(94)00515-X

Hench, L. L., Splinter, R. J., Greenlee, T. K., \& Allen, W. C. (1971). Bonding mechanisms at the interface of ceramic prosthetic materials. Journal of Biomedical Materials Research, 2(part1), 117-141. http://dx.doi.org/10.1002/jbm.820050611

Hench, L. L., \& Paschall, H. A. (1973). Direct chemical bonding of bioactive glass - ceramic materials and bone. Journal of Biomedical Materials Research, 4, 25-42. http://dx.doi.org/10.1002/jbm.820070304

Hench, L. L. (1991). Bioceramics: From Concept to Clinic. Journal of American Ceramic Society, 74, 1487-1510. http://dx.doi.org/10.1111/j.1151-2916.1991.tb07132.x

Jarcho, M., Kay, J. L., Gumaer, R. H., \& Drobeck, H. P. (1977). Tissue, cellular and subcellular events at bone ceramic hydroxyapatite interfaces. Journal of Bioengineering, 1, 79-92.

Kokubo, T., Ito, S., Huang, Z. T., Hayashi, T., Sakka, S., Kitsugi, T., \& Yamamuro, T. (1990). Ca, P - rich layer formed on high - strength bioactive glass - ceramic A - W. Journal of Biomedical Materials Research, 24, 331-343. http://dx.doi.org/10.1002/jbm.820240306

Kokubo, T. (1991). Bioactive glass - ceramics: properties and applications. Biomaterials, 12, 155-163. http://dx.doi.org/10.1016/0142-9612(91)90194-F

Kokubo, T., \& Takadama, H. (2006). How useful is SBF in predicting in vivo bone bioactivity? Biomaterials, 27, 2907-2915. http://dx.doi.org/10.1016/j.biomaterials.2006.01.017

Lin, C. C., Huang, L. C., \& Shen, P. (2005). $\mathrm{Na}_{2} \mathrm{CaSi}_{2} \mathrm{O}_{6}-\mathrm{P}_{2} \mathrm{O}_{5}$ based bioactive glasses. Part 1: Elasticity and structure. Journal of Non - Crystalline Solids, 351, 3195-3203. http://dx.doi.org/10.1016/j.jnoncrysol.2005.08.020

Lusvardi, G., Malavasi, G., Menabue, L., Aina, V., \& Morterra, C. (2009). Fluoride - containing bioactive glasses: Surface reactivity in simulated body fluids solutions. Acta Biomaterialia, 5, 3548-3562. http://dx.doi.org/10.1016/j.actbio.2009.06.009

Marchi, J., Morais, D. S., Schneider, J., Bressiani, J. C., \& Bressiani, A. H. A. (2005). Characterization of rare earth aluminosilicate glasses. Journal of Non - Crystalline Solids, 351, 863-868. http://dx.doi.org/10.1016/j.jnoncrysol.2005.01.078

Mastelaro, V. R., Zanotto, E. D., Lequeux, N., \& Cortes, R. (2000). Relationship between short - range order and ease of nucleation in $\mathrm{Na}_{2} \mathrm{Ca}_{2} \mathrm{Si}_{3} \mathrm{O}_{9}, \mathrm{CaSiO}_{3}$ and $\mathrm{PbSiO}_{3}$ glasses. Journal of Non - Crystalline Solids, 262, 191-199. http://dx.doi.org/10.1016/S0022-3093(99)00685-7

Michel, M. D., Mikowski, A., Lepienski, C. M., Foerster, C. E., \& Serbena, F. C. (2004). High temperature microhardness of soda - lime glass. Journal of Non - Crystalline Solids, 348, 131-138. http://dx.doi.org/10.1016/j.jnoncrysol.2004.08.138

Ogino, M., \& Hench, L. L. (1980). Formation of calcium phosphate films on silicate glasses. Journal of Non Crystalline Solids, 38, 673-678. http://dx.doi.org/10.1016/0022-3093(80)90514-1

Peitl, O., Zanotto, E. D., \& Hench, L. L. (2001). Highly bioactive $\mathrm{P}_{2} \mathrm{O}_{5}-\mathrm{Na}_{2} \mathrm{O}-\mathrm{CaO}-\mathrm{SiO}_{2}$ glass - ceramics. Journal of Non - Crystalline Solids, 292, 115-126. http://dx.doi.org/10.1016/S0022-3093(01)00822-5 
Rahaman, M. N., Day, D. E., Bal, B. S., Fu, Q., Jung, S. B., Bonewald, L. F., \& Tomsia, A. P. (2011). Bioactive glass in tissue engineering. Acta Biomaterialia, 7, 2355-2373. http://dx.doi.org/10.1016/j.actbio.2011.03.016

Rajendran, V., Begum, A. N., Azooz, M. A., \& ElBatal, F. H. (2002). Microstructural dependence on relevant physical - mechanical properties on $\mathrm{SiO}_{2}-\mathrm{Na}_{2} \mathrm{O}-\mathrm{CaO}-\mathrm{P}_{2} \mathrm{O}_{5}$ biological glasses. Biomaterials, 23, 4263-4275. http://dx.doi.org/10.1016/S0142-9612(02)00189-8

Rejda, B. V., Peelen, J. G. L., \& de Groot, K. (1977). Tricalcium phosphate as a bone substitute. Journal of Bioengineering, 1, 93-97.

Serra, J., Gonzalez, P., Liste, S., Chiussi, S., Leon, B., \& Perezamor, M. (2002). Influence of the non - bridging oxygen groups on the bioactivity of silicate glasses. Journal of Materials Science: Materials in Medicine, 13, 1221-1225. http://dx.doi.org/10.1023/A:1021174912802

Verne, E., Bretcanu, O., Balagna, C., Bianchi, C. L., Cannas, M., Gatti, S., \& Brovarone, C. V. (2009). Early stage reactivity and in vitro behavior of silica - based bioactive glasses and glass - ceramics. Journal of Materials Science: Materials in Medicine, 20, 75-87. http://dx.doi.org/10.1007/s10856-008-3537-8

Wang, M., Cheng, J., Li, M., \& He, F. (2011). Structure and properties of soda lime silicate glass doped with rare earth. Physica B, 406, 187-191. http://dx.doi.org/10.1016/j.physb.2010.10.040

Table 1. Composition of bioactive glasses

\begin{tabular}{|c|c|c|c|c|c|c|}
\hline \multirow{2}{*}{ Code for glasses } & \multicolumn{5}{|c|}{ Composition (wt \%) } & \multirow{2}{*}{ Code for glass - ceramics } \\
\cline { 2 - 5 } & $\mathrm{SiO}_{2}$ & $\mathrm{Na}_{2} \mathrm{O}$ & $\mathrm{CaO}$ & $\mathrm{P}_{2} \mathrm{O}_{5}$ & $\mathrm{ZnO}$ & 45S5C \\
\hline $45 \mathrm{~S} 5$ & 45.00 & 24.50 & 24.50 & 6.00 & - & $\mathrm{Z} 1 \mathrm{C}$ \\
\hline $\mathrm{Z} 1$ & 44.00 & 24.50 & 24.50 & 6.00 & 1.00 & $\mathrm{Z} 2 \mathrm{C}$ \\
\hline $\mathrm{Z} 2$ & 43.00 & 24.50 & 24.50 & 6.00 & 2.00 & $\mathrm{Z} 3 \mathrm{C}$ \\
\hline $\mathrm{Z} 3$ & 42.00 & 24.50 & 24.50 & 6.00 & 3.00 & $\mathrm{Z} 4 \mathrm{C}$ \\
\hline $\mathrm{Z} 4$ & 41.00 & 24.50 & 24.50 & 6.00 & 4.00 & \\
\hline
\end{tabular}

Table 2. Heat treatment schedule for crystallization of bioactive glasses

\begin{tabular}{|c|c|c|c|c|}
\hline \multirow{2}{*}{ Sample } & \multicolumn{2}{|c|}{ Nucleation } & \multicolumn{2}{c|}{ Growth } \\
\cline { 2 - 5 } & Temperature $\left({ }^{\circ} \mathrm{C}\right)$ & Time (hours) & Temperature $\left({ }^{\circ} \mathrm{C}\right)$ & Time (hours) \\
\hline 45 S5 & 533 & 6 & 717 & 3 \\
\hline Z1 & 528 & 6 & 686 & 3 \\
\hline Z2 & 524 & 6 & 671 & 3 \\
\hline Z3 & 521 & 6 & 661 & 3 \\
\hline Z4 & 518 & 6 & 651 & 3 \\
\hline
\end{tabular}

Table 3. Ion concentration of simulated body fluid and human blood plasma [12]

\begin{tabular}{|c|c|c|c|c|c|c|c|c|}
\hline \multicolumn{10}{|c|}{ Ion concentration (mM) } \\
\hline Ion & $\mathrm{Na}^{+}$ & $\mathrm{K}^{+}$ & $\mathrm{Mg}^{2+}$ & $\mathrm{Ca}^{2+}$ & $\mathrm{Cl}^{-}$ & $\mathrm{HCO}_{3}^{-}$ & $\mathrm{HPO}_{4}^{-}$ & $\mathrm{SO}_{4}{ }^{2-}$ \\
\hline Simulated body fluid & 142.0 & 5.0 & 1.5 & 2.5 & 147.8 & 4.2 & 1.0 & 0.5 \\
\hline Human blood Plasma & 142.0 & 5.0 & 1.5 & 2.5 & 103.0 & 27.0 & 1.0 & 0.5 \\
\hline
\end{tabular}

Table 4. Density $(\rho)$, micro hardness $(H)$ and flexural strength $\left(\sigma_{f}\right)$ of bioactive glasses and glass - ceramics

\begin{tabular}{|c|c|c|c|c|c|c|c|}
\hline \multicolumn{5}{|c|}{ Glasses } & \multicolumn{4}{c|}{ Glass - ceramics } \\
\hline Sample & $\rho\left(\mathrm{g} / \mathrm{cm}^{3}\right)$ & $H(\mathrm{GPa})$ & $\sigma_{f}(\mathrm{MPa})$ & Sample & $\rho\left(\mathrm{g} / \mathrm{cm}^{3}\right)$ & $H(\mathrm{GPa})$ & $\sigma_{f}(\mathrm{MPa})$ \\
\hline 45S5 & 2.707 & 5.75 & 43.48 & $45 \mathrm{~S} 5 \mathrm{C}$ & 2.912 & 7.70 & 104.17 \\
\hline Z1 & 2.727 & 5.85 & 50.45 & Z1C & 2.928 & 7.86 & 110.49 \\
\hline Z2 & 2.736 & 5.90 & 54.26 & Z2C & 2.936 & 7.93 & 113.24 \\
\hline Z3 & 2.752 & 6.01 & 60.15 & Z3C & 2.951 & 8.06 & 118.31 \\
\hline Z4 & 2.764 & 6.08 & 65.37 & Z4C & 2.962 & 8.15 & 122.16 \\
\hline
\end{tabular}




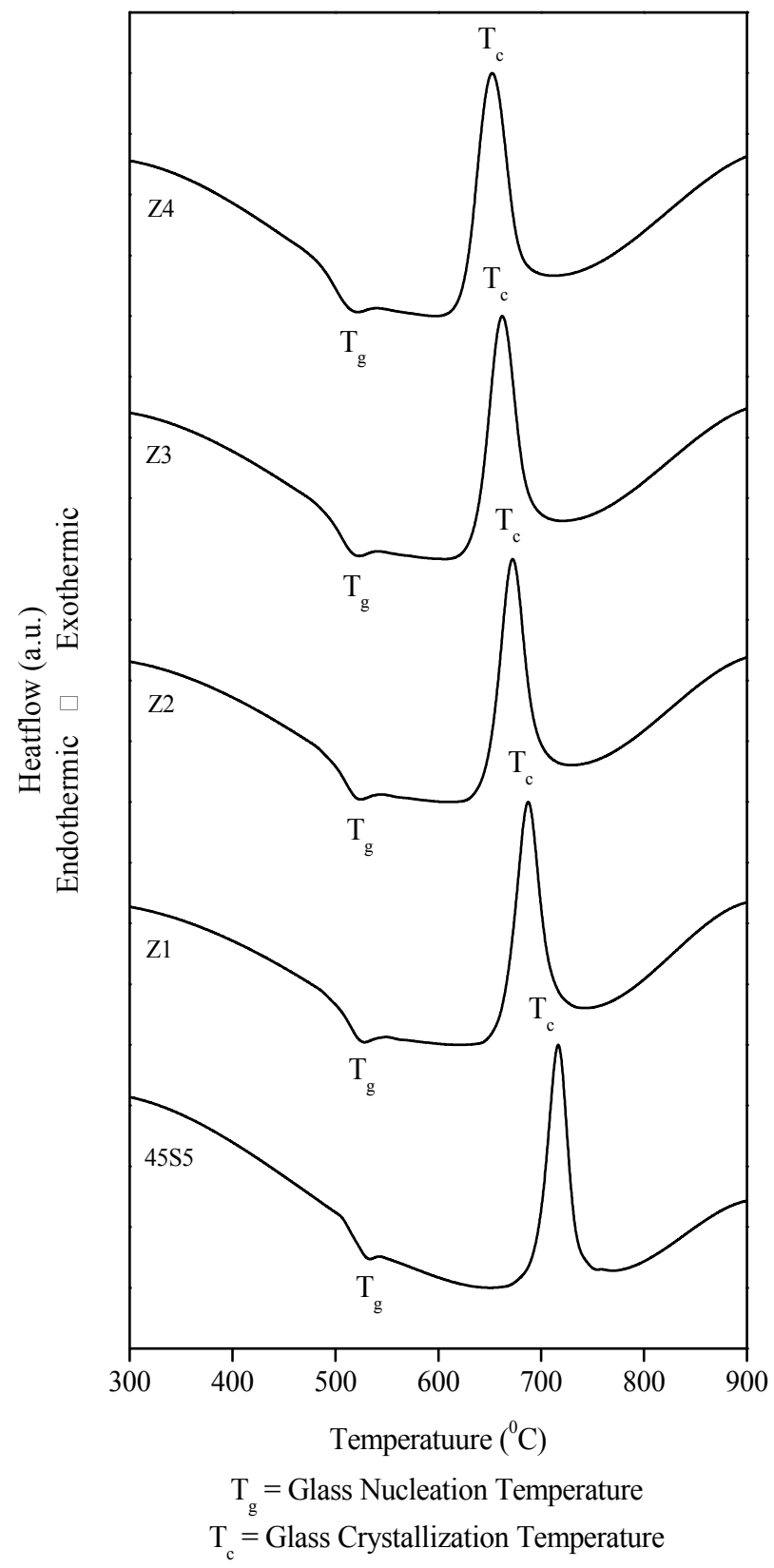

Figure 1. Differential thermal analysis (DTA) plots of bioactive glasses 


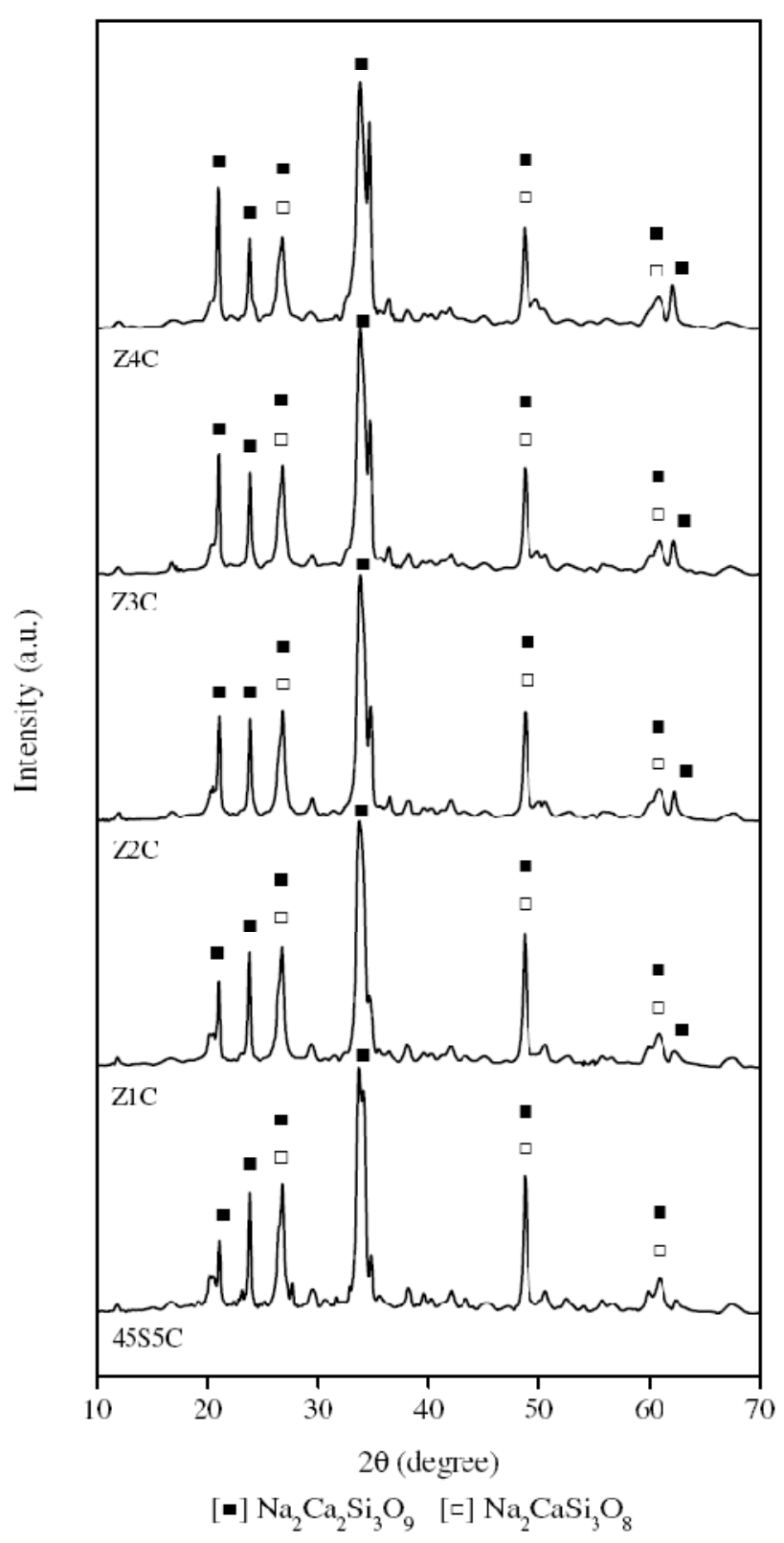

Figure 2. X - ray diffraction (XRD) patterns of bioactive glass - ceramics 


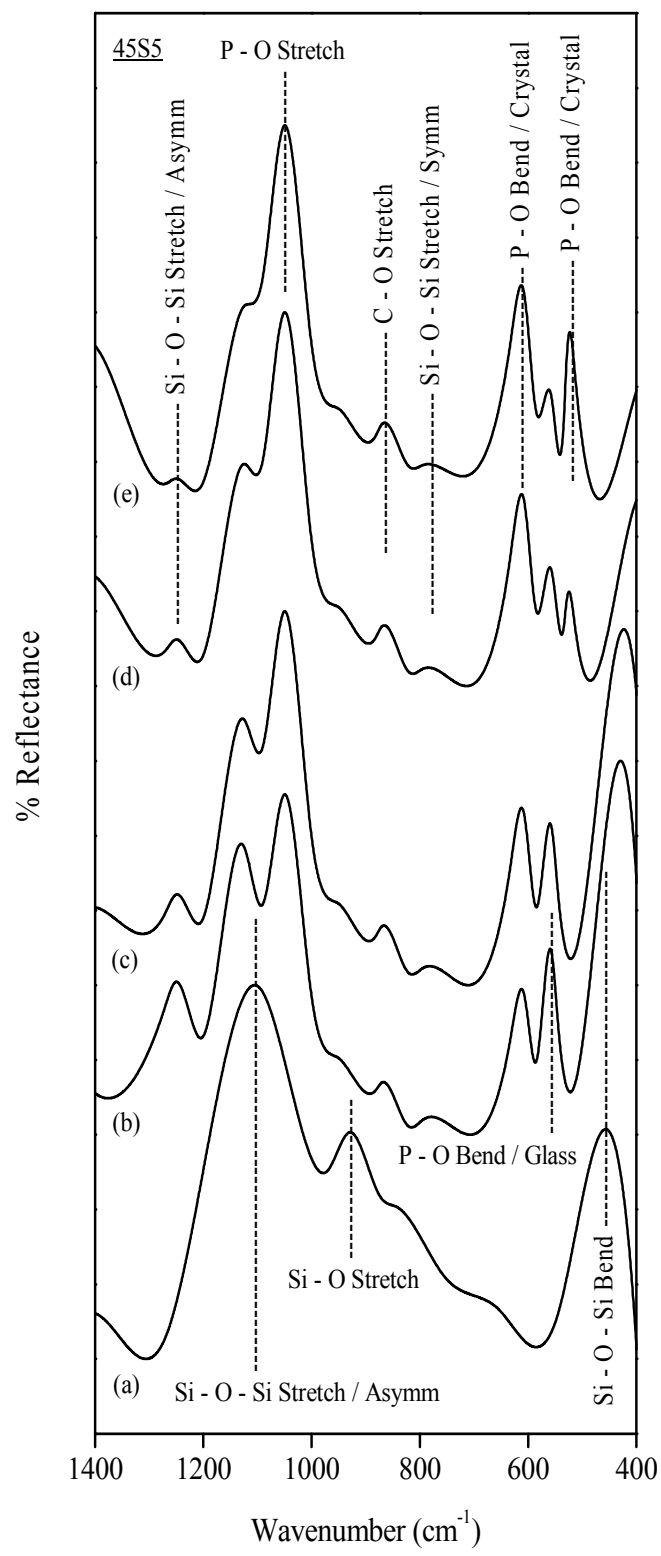

(A)

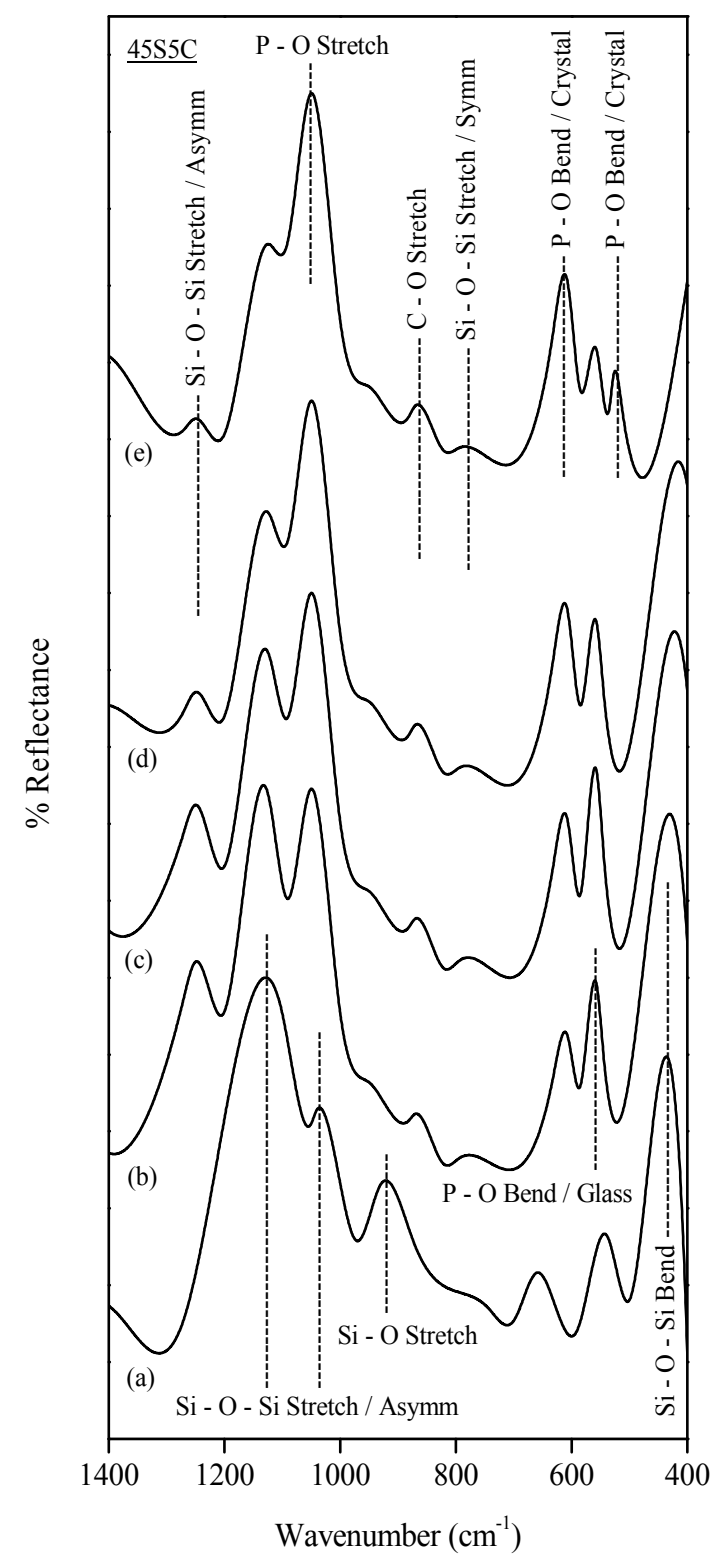

(B)

Figure 3. Fourier transform infrared (FTIR) reflectance spectra of (A) bioactive glass 45S5 (B) bioactive glass ceramic 45S5C, (a) before (b), (c), (d) and (e) after soaking for a period of 1, 3, 7 and 15 days in SBF solution 


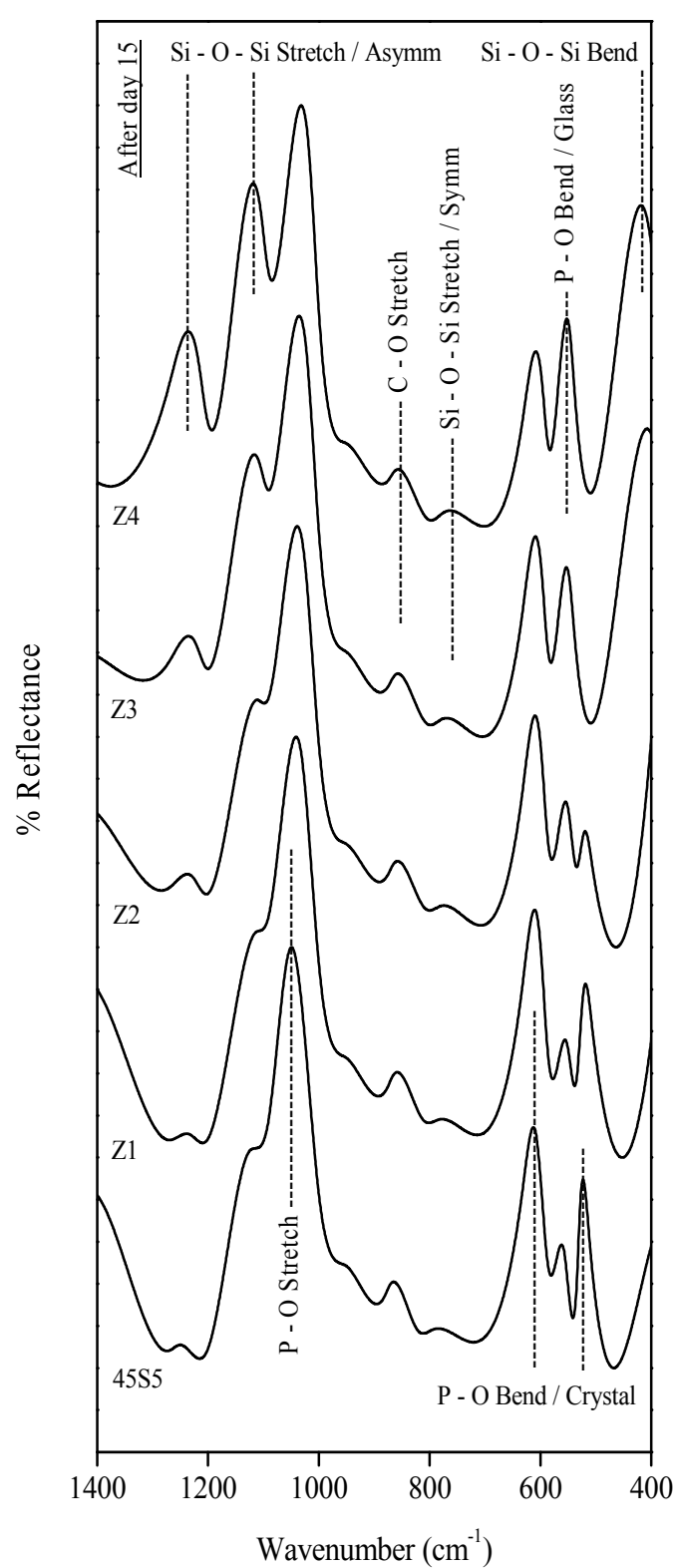

(A)

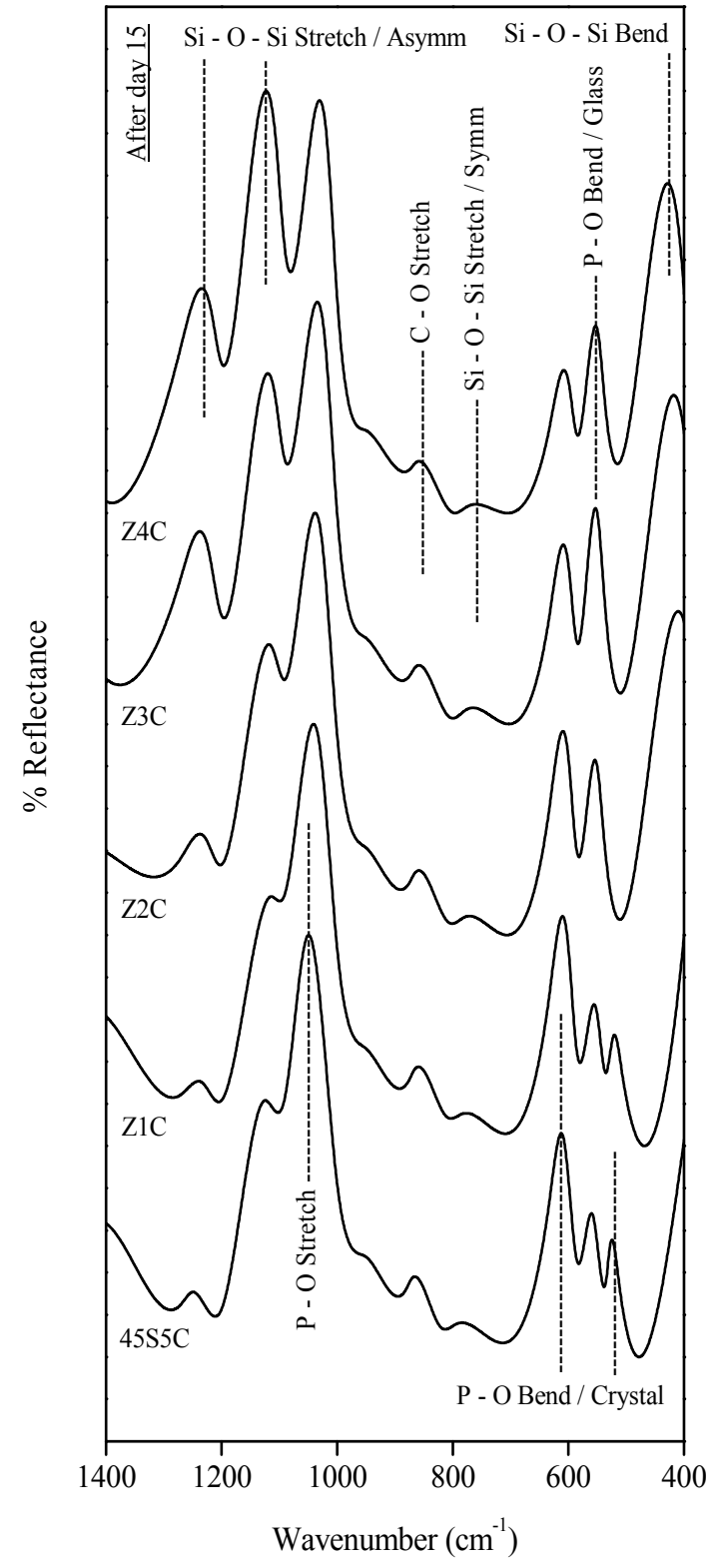

(B)

Figure 4. Fourier transform infrared (FTIR) reflectance spectra of (A) bioactive glasses (B) bioactive glass ceramics after soaking for a period of 15 days in SBF solution 

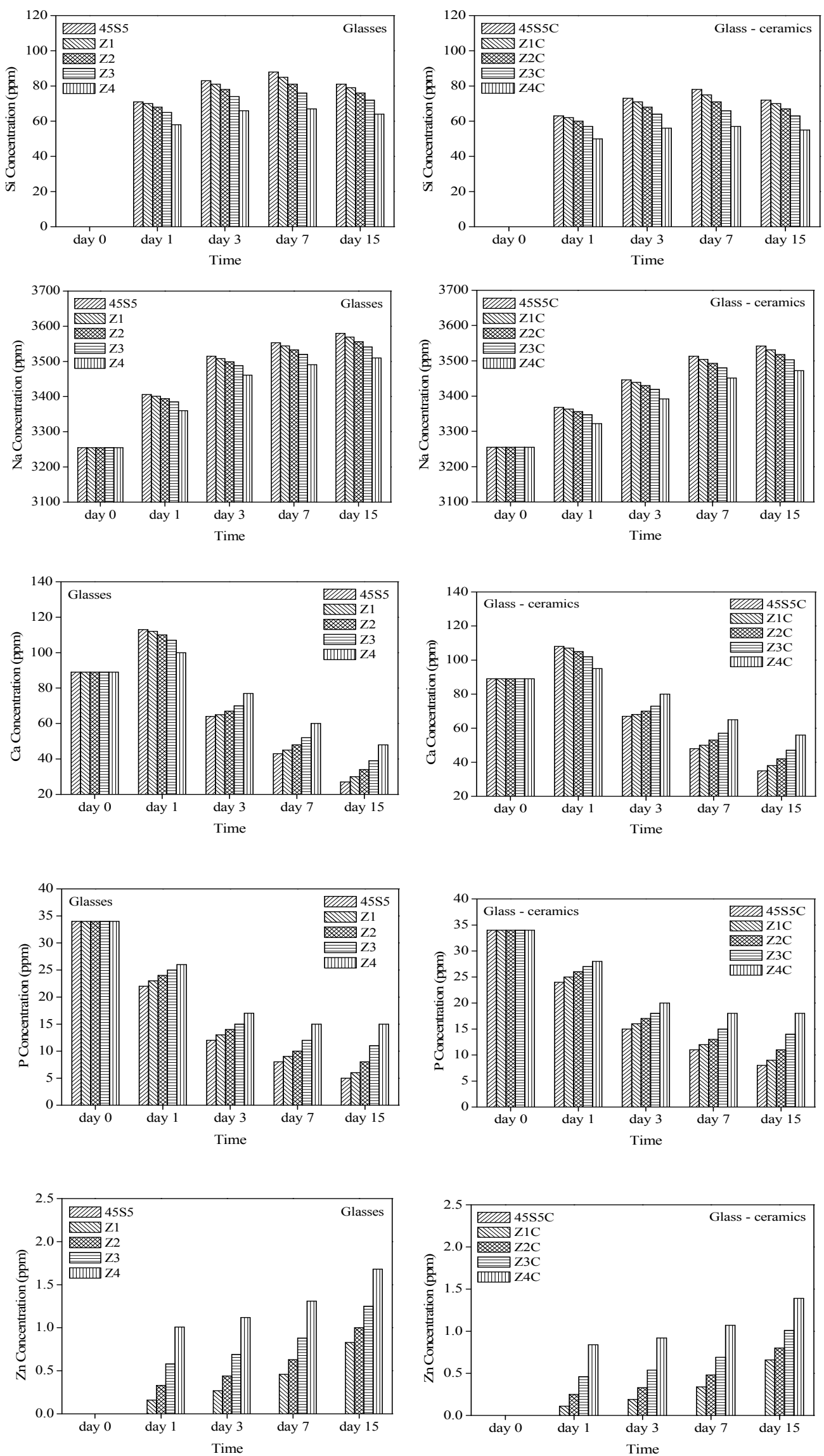

Figure 5. Si, $\mathrm{Na}, \mathrm{Ca}, \mathrm{P}$ and $\mathrm{Zn}$ concentrations in $\mathrm{SBF}$ solution that was taken before and after soaking of bioactive glasses and glass - ceramics for a period of $1,3,7$ and 15 days 

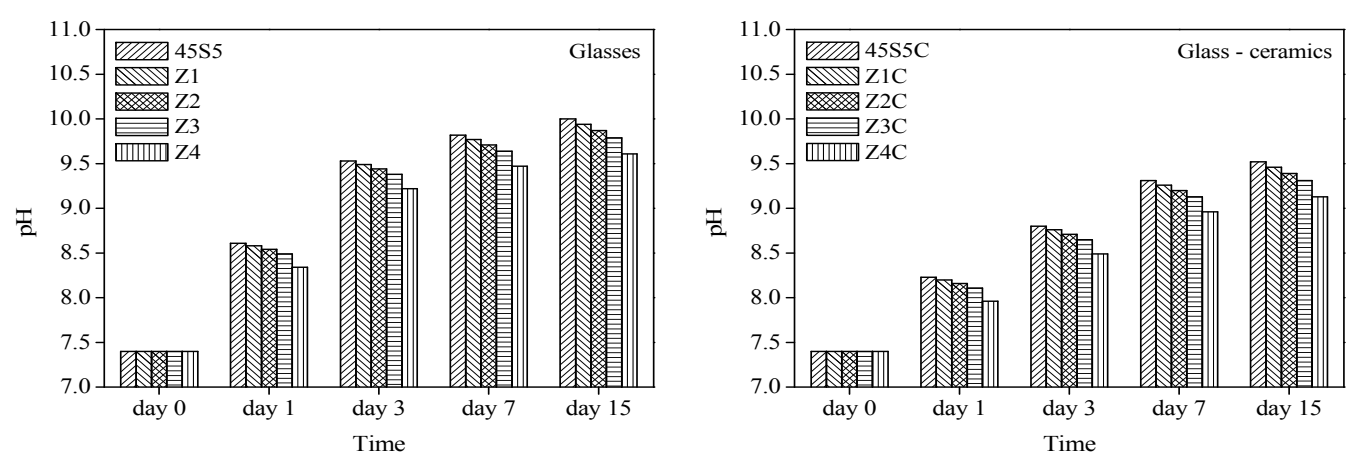

Figure 6. $\mathrm{pH}$ of SBF solution that was taken before and after soaking of bioactive glasses and glass - ceramics for a period of $1,3,7$ and 15 days 